\title{
COVID -19 Pandemic and Level of Responses in Bangladesh
}

\section{Md Kariul Islam, MSS, MPH ${ }^{*}$, Md Shukur Ali, PhD², SAM Ziaur Rahman Akanda, MSc ${ }^{3}$, Shahnaz Rahman, $B A^{4}, A H M$ Kamruzzaman, $M B A, D B A^{5}$, Sharif Abdul Kader Pavel, $M_{P H}{ }^{6}$ and Jannatul Baki, $M B A^{7}$}

\author{
${ }^{1}$ Chief Researcher, International Online Journal Hub-IOJH, Bangladesh \\ ${ }^{2}$ Senior Consultant, International Online Journal Hub-IOJH, Bangladesh \\ ${ }^{3}$ Director (Research \& Development), International Online Journal Hub-IOJH, Bangladesh \\ ${ }^{4}$ Public Relation Officer, International Online Journal Hub-IOJH, Bangladesh \\ ${ }^{5}$ General Manager (Sales and Marketing), SA Group of Industries, Bangladesh \\ ${ }^{6}$ Director (Communication), International Online Journal Hub-IOJH, Bangladesh \\ ${ }^{7}$ Manager, International Online Journal Hub-IOJH, Bangladesh
}

*Corresponding author: Md Kariul Islam, Chief Researcher, MSS (Economics), MPH (Epidemiology), International Online Journal Hub-IOJH, Dhaka, Bangladesh

\begin{abstract}
Background: Bangladesh is a South East Asian natural beautiful middle income country. Its economy is flourishing rapidly. In the last decade immense development has been noticed in every sphere of life including women empowerment. However, incidence of COVID-19 Pandemic has influenced every sector of Bangladesh badly. COVID-19 is the pandemic disease declared by World Health Organization (WHO) on $11^{\text {th }}$ March 2020 [1] which is potentially severe acute respiratory infection caused by a novel evolving severe acute respiratory syndrome corona virus2 (SARSCoV-2). The virus was identified as the cause of an outbreak of pneumonia of unknown cause in Wuhan City, Hubei Province, China, in December 2019. The clinical presentation is that of a respiratory infection with a symptom severity ranging from a mild influenza like illness, to a severe viral pneumonia leading to acute respiratory distress syndrome that is potentially fatal. Globally 199 countries are reported to have the pandemic going on and the situation is evolving rapidly with global case counts and deaths increasing each day. The World Health Organization rates the global risk assessment as very high and community transmission is occurring in many countries, but it is uncertain how easily the virus spreads between people. Bangladesh is also declared the COVID-19 infection reported from Directorate General of Health Service on daily basis with 48 confirmed case and 5 death having community transmission (dated $28^{\text {th }}$ March, 2020) [2]. However, COVID-19 community transmission and
\end{abstract}

death tolls are the burning issues of the present world. So, the researchers designed this study to explore an over view on COVID-19 situation in Bangladesh as of $14^{\text {th }}$ May, 2020, on the basis of secondary literature review.

Methods: This study was a descriptive secondary literature review conducted by International Online Journals Hubs (IOJH)- A Dynamic Center for Research Consultancy \& Publication, Dhaka, Bangladesh during $8^{\text {th }}$ March to $14^{\text {th }}$ May, 2020. During this study, the researchers of IOJH reviewed the update press release, provided by IEDCR, varieties of newspapers, electronic news media, Google Wikipedia and update report provided by World Health Organization (WHO) on Corona Virus (COVID-19) situation in Bangladesh. Then the researchers check and cross check the update data to finalize and confirm the concerned issue and variables of this study. The researchers used simple statistical tools to analyze the collected data.

Results: As of 14 May, 2020, a total of 151930 samples were tested, of them 18863 COVID-19 positive cases were identified, of them, 283 people were died and 3361 people recovered from COVID-19. COVID-19 positive cases from 8 March to 31 March, 2020, during these 24 days total 51 positive cases were identified in Bangladesh. The average positive cases were 2.12 per day as of 31 March, 2020. COVID-19 positive cases from 1 April to 30 April, 2020, during these 30 days total 7616 positive cases were identified in Bangladesh. The average positive cases were 253.86 per day as of 30 April, 2020. COVID-19 positive cases from

Citation: Islam K, Ali S, Akanda SZR, Rahman S, Kamruzzaman AHM, et al.(2020) COVID -19 Pandemic and Level of Responses in Bangladesh. Int J Rare Dis Disord 3:019. doi.org/10.23937/26434571/1710019

Received: May 27, 2020; Accepted: August 22, 2020; Published: August 24, 2020

Copyright: (C) 2020 Islam K, et al. This is an open-access article distributed under the terms of the Creative Commons Attribution License, which permits unrestricted use, distribution, and reproduction in any medium, provided the original author and source are credited. 
$1^{\text {st }}$ May to 14 May, 2020 , during these 14 days total 11196 positive cases were identified in Bangladesh. The average positive cases were 799.71 per day as of 14 May, 2020. As of March 8 to May 14,2020, total COVID-19 positive cases were 18863 persons, of them $\leq 10$ years were $3 \%, 11-20$ years were $8 \%, 21-30$ years were $26 \%, 31-40$ years were $24 \%, 41-50$ years were $18 \%, 51-60$ years were $13 \%$ and above 60 years were $8 \%$. Among the total positive cases, $68 \%$ were male and $32 \%$ were female patients. During the first tests on 8 March to till May-1, 51,930 samples were tested, of them 18863 positive cases were identified. Average tests per day were 2234.26 and average positive cases per day were 277.39 identified. However, during this time, total 283 COVID positive patients were died. The average deaths were 4.16 persons per day. On the other hand, total 3361 patients were recovered from COVID-19. Amon the total positive cases, as of 14 May, 2020 , a total of 283 COVID positive patients were died, of them $\leq 10$ years were $2 \%$, $11-20$ years were $0 \%, 21-30$ years were $3 \%, 31-40$ years were $7 \%, 41-50$ years were $19 \%, 51-60$ years were $27 \%$ and above 60 years were $42 \%$. Among the deaths, $73 \%$ were male and $27 \%$ were female. So it can be said male were more vulnearable to death than that of female COVID-19 positive cases.

Conclusion: From this study, it is vivid that Corona Virus (COVID-19) transmission is increasing in an alarming rate in Bangladesh, retiring all the government and non-government responses. Hence the national task force needs to be more strict to stop community transmission of corona virus as well as a high-tech technology needs to be introduced to the physicians and health workers to take care of the COVID-19 patients in Bangladesh to end this pandemic.

\section{Keywords}

Pandemic, COVID-19, Response

\section{Introduction}

Bangladesh is a South East Asian natural beautiful middle income country. Its economy is flourishing rapidly. In the last decade immense development has been noticed in every sphere of life including women empowerment. However, incidence of COVID-19 Pandemic has influenced every sector of Bangladesh badly. The area of Bangladesh is about $1,47,570 \mathrm{~s} \mathrm{~km}$ and about $160 \mathrm{mil}-$ lion people live here with peace and amity. Naturally, the density of population of this country is very high in comparing to some other developed countries of the world. Hence, Corona Virus (COVID-19) Pandemic has become the worst threat to the life of the people of this country and its economy as well as development. Anyway, to the reference of medical science, corona viruses are enveloped as a non-segmented positive sense RNA viruses belonging to the family Coronaviridae and the Order Nidovirales and broadly distributed in humans and other mammals [3]. Currently estimates of the incubation period of the virus range from 2-10 days. COVID-19 was discovered in 2019, which is responsible for global pandemic. So far as we know, the first contamination was made from bats to the people of a market of Wuhan city in China where wild birds and beasts were sold. So, China is the first affected country and birth place of COVID-19 contamination from bats to humans. Later, it has been spread to number of other countries around the world to a varying degree. The virus initially referred as 2019-nCoV and familiarly called "Wuhan corona virus". World health organization named it as COVID-19 because it doesn't refer to any geographical area, an animal, a person, or group people all of which can lead to stigma. The virus officially named as SARS CoV-2, which is genetically very similar to SARS Corona virus. Corona viruses are a large family of viruses that usually cause mild to moderate upper-respiratory tract illnesses namely common cold and respiratory distress [1]. However, three times in the $21^{\text {st }}$ century corona virus outbreaks have arisen from animal reservoirs, now the present virus epidemic from Wuhan city, china. Most of the virus circulates among animals including pigs, camels, bats and cats. Rarely, animal corona viruses that infect animals have emerged to infect people and can spread. However, COVID-19 community transmission and death tolls are the burning issues of the present world. So, the researchers designed this study to explore an over view on COVID-19 situation in Bangladesh as of 14 May, 2020, on the basis of secondary literature review.

\section{Objective}

To explore an over view on Corona Virus (COVID-19) pandemic situation in Bangladesh.

\section{Methodology and Materials}

This study was a descriptive secondary literature review conducted by International Online Journals Hubs (IOJH)-A Dynamic Center for Research Consultancy \& Publication, Dhaka, Bangladesh during $8^{\text {th }}$ March to 14 May, 2020. During this study, the researchers of IOJH reviewed the update press release, provided by IEDCR, varieties of newspapers, electronic news media, Google Wikipedia and update report provided by World Health Organization (WHO) on Corona Virus (COVID-19) situation in Bangladesh. Then the researchers checked and cross checked the update data to finalize and confirm the concerned issue and variables of this study. The researchers used simple statistical tools to analyze the collected data.

\section{Results and Discussion}

Figure 1 shows that $1^{\text {st }}$ month ( $8^{\text {th }}$ March, 2020 to $4^{\text {th }}$ April, 2020) confirmed cases were not going up. From $5^{\text {th }}$ April 2020, it was started increasing slowly and a peak on $9^{\text {th }}$ May 2020 . Then was started going up rapidly.

Table 1 shows the total positive cases month wise and average positive cases/day. From March 8 to 31 March the total 51 positive cases were identified. During this time average transmission was 2.12 and in April the total 7616 positive cases were identified. During April average positive cases were 253.86 per day. However, on May 1 to May-14, during these 14 days total 11196 COVID-19 positive cases were identified across the 


\section{Trend of confirmed Cases}

1400

1200

1000

800

600

400

200

0

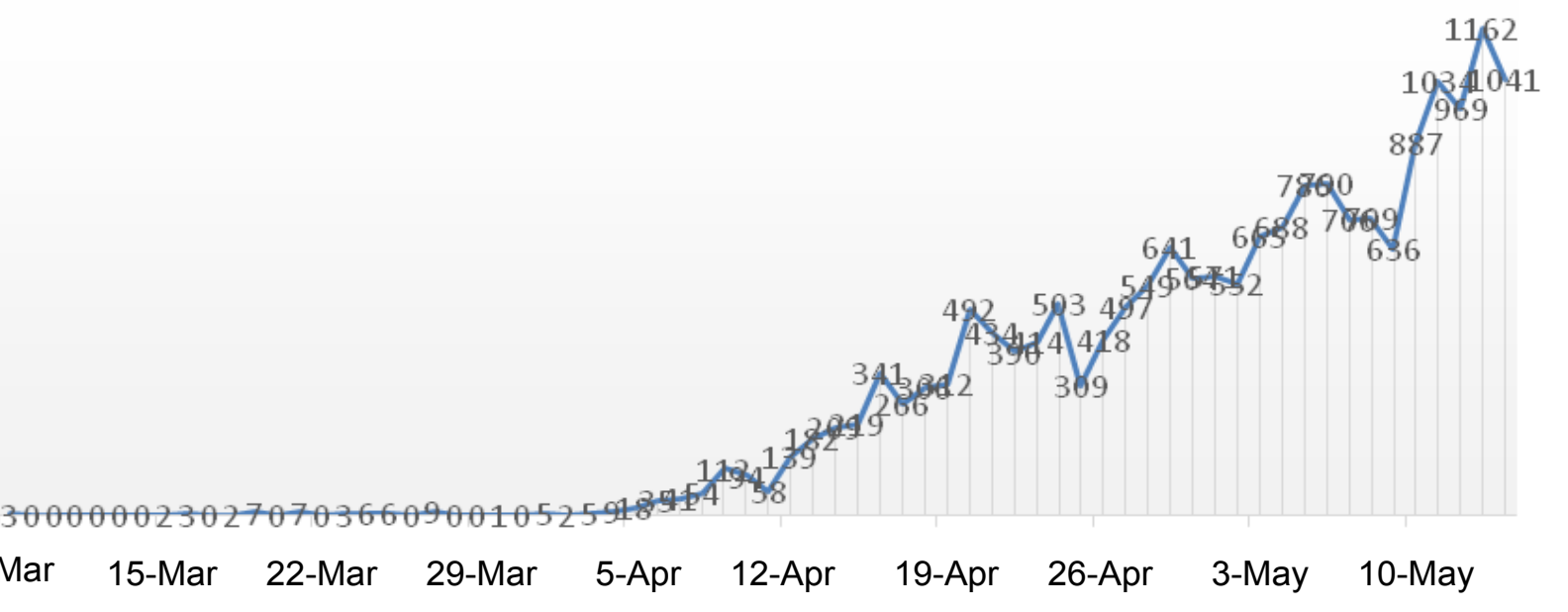

Figure 1: COVID-19 positive cases in Bangladesh from 8 March, 2020 to 14 May, 2020.

Table 1: Total positive cases month wise and average positive cases/day.

\begin{tabular}{|l|l|l|}
\hline Month & $\begin{array}{l}\text { Total positive } \\
\text { Cases }\end{array}$ & $\begin{array}{l}\text { Average psitive } \\
\text { Cases/day }\end{array}$ \\
\hline March & 51 & 2.12 \\
\hline April & 7616 & 253.86 \\
\hline May-1 to May-14 & 11196 & 799.71 \\
\hline As of 14 May, 2020 total positive cases & 18863 \\
\hline
\end{tabular}

Table 2: Age distribution of the COVID-19 positive cases.

\begin{tabular}{|l|l|}
\hline Age & $\%$ \\
\hline$\leq 10$ & 3 \\
\hline $11-20$ & 8 \\
\hline $21-30$ & 26 \\
\hline $31-40$ & 24 \\
\hline $41-50$ & 18 \\
\hline $51-60$ & 13 \\
\hline Above 60 & 8 \\
\hline
\end{tabular}

country and the average positive cases per day were 799.71. The trend of COVID-19 positive cases were on the increase rapidly [4].

Table 2 shows the age distribution of the COVID-19 positive cases. As of March 8 to May 14, 2020, total COVID-19 positive cases were 18863 persons, of them $\leq 10$ years were $3 \%, 11-20$ years were $8 \%, 21-30$ years were $26 \%$, $31-40$ years were $24 \%$, $41-50$ years were $18 \%, 51-60$ years were $13 \%$ and above 60 years were $8 \%[4]$.

Figure 2 shows the gender distribution of the COVID-19 positive cases. Among the total positive cases, $68 \%$ were male and $32 \%$ were female patients [4].

Table 3 shows the total tested persons, positive cas-

\section{Male $\quad$ Female}

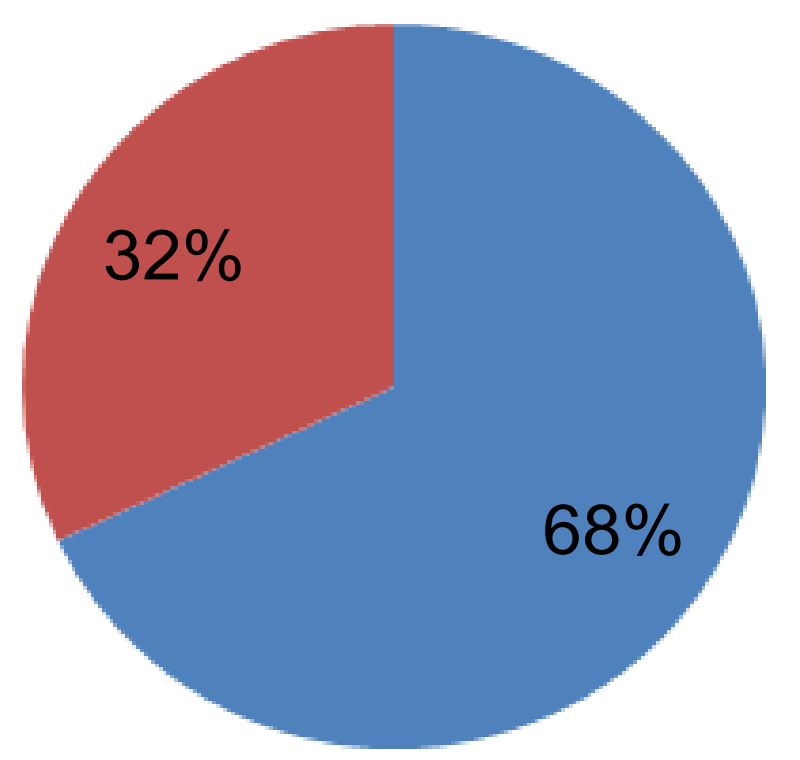

Figure 2: Gender distribution of the positive cases COVID-19.

es, deaths, recovered cases and their average/day as of 14, 2020. May, 2020. During the first tests on 8 March to till May-14, 151,930 persons were tested, of them 18863 positive cases were identified. Average tests per day were 2234.26 and average positive cases per day were 277.39 identified. However, during this time, total 283 COVID positive patients were died [5]. The average deaths were 4.16 persons per day. On the other hand, total 3361 persons were recovered from COVID-19. Average recovered rate per day were 49.92 persons.

Table 4 shows the age distribution of the death cases of COVID-19. Amon the total positive cases as of 14 May, 2020, a total of 283 COVID positive patients were 
Table 3: Total tested persons, positive cases, deaths and recovered cases and their average/day as of 14 May, 2020.

\begin{tabular}{|l|l|l|l|l|l|l|l|}
\hline $\begin{array}{l}\text { Total } \\
\text { Tested }\end{array}$ & $\begin{array}{l}\text { Average } \\
\text { Tested/Day }\end{array}$ & $\begin{array}{l}\text { Total } \\
\text { Positive } \\
\text { Cases }\end{array}$ & $\begin{array}{l}\text { Average } \\
\text { Positive } \\
\text { Cases/day }\end{array}$ & $\begin{array}{l}\text { Total } \\
\text { deaths }\end{array}$ & $\begin{array}{l}\text { Average } \\
\text { deaths/day }\end{array}$ & $\begin{array}{l}\text { Total } \\
\text { Recovered }\end{array}$ & $\begin{array}{l}\text { Average } \\
\text { Recovered/day }\end{array}$ \\
\hline $1,51,930$ & $2,234.26$ & 18863 & 277.39 & 283 & 4.16 & 3361 & 49.92 \\
\hline
\end{tabular}

Table 4: Age Distribution of the death cases COVID 19.

\begin{tabular}{|l|l|}
\hline Age & $\%$ \\
\hline$\leq 10$ & 2 \\
\hline $11-20$ & 0 \\
\hline $21-30$ & 3 \\
\hline $31-40$ & 7 \\
\hline $41-50$ & 19 \\
\hline $51-60$ & 27 \\
\hline Above 60 & 42 \\
\hline
\end{tabular}

\section{Male Female}

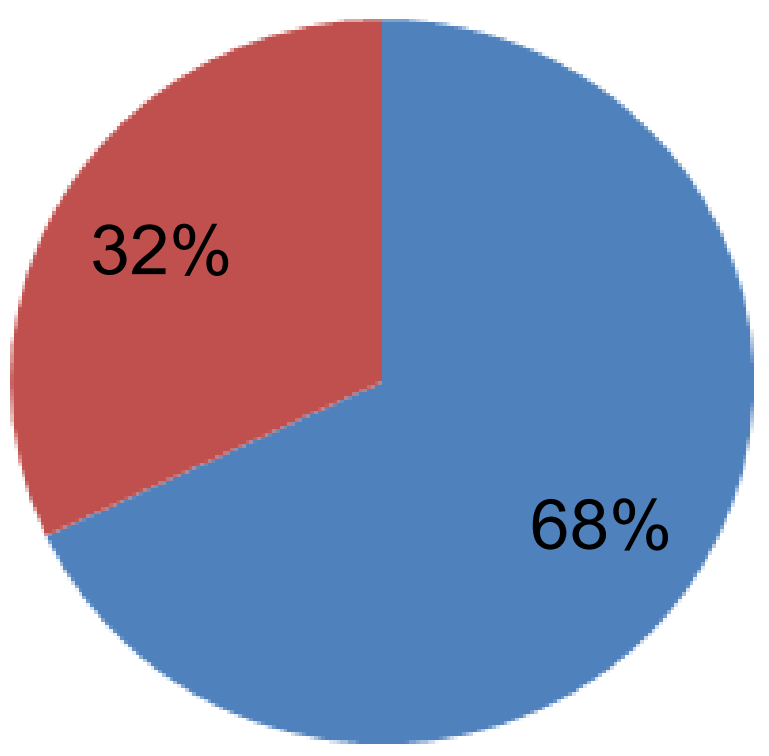

Figure 3: Gender distribution of the death cases COVID-19.

died, of them $\leq 10$ years were $2 \%, 11-20$ years were $0 \%$, $21-30$ years were $3 \%, 31-40$ years were $7 \%, 41-50$ years were $19 \%$, $51-60$ years were $27 \%$ and above 60 years were $42 \%$.

Figure 3 shows the gender distribution of the death cases COVID-19. As of 14 May, 2020, a total of 283 COVID-19 positive patients were died, of them $73 \%$ were male and $27 \%$ were female. So it can be said that tme male were more vulnearable to death than that of female COVID-19 positive cases.

\section{Treatment Procedure of Covid-19 Patients in Bangladesh}

A National Committee has been formed by the Ministry of Health and Family Welfare and this committee produced national guidelines with the recommendation of World Health Organization on clinical management of COVID-19 patients of all ages including infants and mothers. The National Guidelines on Clinical management of COVID-19 includes the following items [2]:

Introduction

1. Virology

2. Case Definition

3. Clinical Syndromes associated with COVID-19

4. Testing for COVID-19

5. Management/Treatment

6. Pharmacotherapy

7. Caring for infants and mother with COVID-19: IPC and breastfeeding

8. Caring for older persons with COVID-19

9. Avoiding medical damage in special populations

10.Discharge criteria

11. Home isolation

\section{Follow up}

13. Management of patients tested positive again after discharge

[Source: National Guidelines on Clinical Management of COVID-19].

\section{Government Response}

The Government of Bangladesh took a great many initiatives to control COVID-19 transmission in Bangladesh from the very early when it first prevailed at Wuhan city in China. But COVID-19 pandemic is a global phenomenon at one point on 8 March, 2020 it prevailed in Bangladesh and 03 COVID-19 patients were identified first in the country. So before and after March, 2020, the government took some initiatives to control COVID-19 transmission among Bangladeshi people such as evacuations, travel and entry restrictions, social distancing measures, fighting disinformation, shutting down of schools, colleges, universities as well as all types of educational institutes, stopping mass vehicles, and finally imposing lockdown on Dhaka city and then the other districts gradually on the basis of COVID-19 transmission, ensuring of testing and treatment of COVID-19 patients in govt. and in some private hospitals and clinics across the country, creating awareness among the people about COVID-19 symptoms through mass media, identifying the house of the returnees of abroad and locking down them, deploying of Army besides police and others law enforcing agencies to ensure 
lockdown, providing reliefs goods to the workless people during the lockdown, declaring general holidays, announcing stimulus package for the garment industries, declaring the remission of bank interest during the lock down, providing daily necessaries with low price by TCB, driving mobile court to keep control the market price as usual, providing rice to the distress and poor people with $10 \mathrm{tk} / \mathrm{kg}$ of rice, asking the moneyed men to help the poor, workless people during the lockdown etc are mentionable [6].

\section{Non Government Response}

Besides government, some non-government organizations, businessmen, politicians as well as social workers are found to provide foods and other aids to the poor workless people during the lockdown. Bashundhara Group, - the most prominent and the largest business group of the country, has already built a large 2000 bedded hospital with the permission of the government of Bangladesh for the treatment of the COVID-19 patients at Bashundhara Residential Area with their own cost and management. They are also providing masks and PPE to the hospitals and to the government and non-government institutions that are rendering services during the lockdown. Some other businessmen were also found to provide donation to the office of the Prime Minister of Bangladesh [6].

\section{World Health Organization (WHO) Response}

World Health Organization (WHO) is continuously monitoring the COVID-19 situation in Bangladesh. World Health Organization (WHO) is coordinating the government to control the COVID-19 infection and transmission among the people in Bangladesh. They have produced 11 reports till now on the outbreak of COVID-19 situation in Bangladesh and its testing, treatment procedure and death cases.

As of 4 May 2020, according to the Institute of Epidemiology, Disease Control and Research (IEDCR), there are 10,143 confirmed COVID-19 cases in Bangladesh, including 182 related deaths; Case Fatality Rate (CFR) is $1.79 \%$.

The World Health Organization has outlined six criteria that each country should meet before lifting restrictions. These are criteria that any country should use to keep transmission of COVID-19 low and at manageable levels. These steps can help countries gradually lift restrictions in phases; will allow some resumption of economic and social life, while minimizing the risk of disease [7]:

1. Transmission of corona virus is under control;

2. The health system is able to detect, test, isolate and treat every case and trace every contact;

3. The risk of outbreak hotspots is minimized in vulnerable settings like health facilities;
4. Workplaces, schools, and other essential places have preventive measures in place;

5. Measures are in place to manage the risk of importing new cases; and

6. Communities are fully educated, engaged and empowered to adjust to the new norms.

\section{Why are they important?}

The six criteria outline what should be in place before transitioning away from these measures currently in place, such as physical distancing and "shutdowns". This "slow and strategic" response is necessary because the virus spreads rapidly and outbreaks can occur quickly. There are no new vaccines or medicines to prevent or treat COVID-19. Physical distancing measures and movement restrictions are effective in slowing the spread of the virus by limiting contact between people. If these measures are lifted too early or too quickly it is likely to lead to a sharp increase in COVID-19 cases.

\section{What they are not?}

These six steps do not guarantee that COVID-19 will not re-emerge or increase. Without vaccines or medicines, our societies must balance the need and hardship of physical distancing measures to control COVID-19 and the need to resume important activities in our lives. As these six criteria are applied, decisions about when and where to move away from restrictions should be based on real time assessments of disease activity. Measures should be lifted in a phased, step-by-step manner.

[Source: Report 10 provided by World Health Organization on COVID-19 situation in Bangladesh].

\section{Digital Technology for COVID-19 Response}

Bangladesh is a developing middle income country. Science and information technology of this country is on the increase. This country is not fully digitalized yet. Due to financial constraints, many of the people of this country are out of virtual technology. There are so many slum dwellers and rootless flatter people in this country. They cannot afford to internet facilities and virtual devices. At the same time, they are not skilled enough to operate virtual devices. But virtual technology is a very effective weapon to control corona virus (COVID-19) transmission. So, this may be one of the causes of increasing COVID-19 transmission in Bangladesh. However, virtual technologies are termed as Virtual Reality (VR) through which face to face interaction can be reduced between the doctors and infected COVID-19 patients. Virtual Reality (VR) also offers an imperative role for fighting pandemic (COVID-19), through audiovisual-based virtual communication. VR is also beneficial for remote sites for exploring telemedicine, planning, treatment, and controlling of the infections by providing proper awareness to the people regarding this disease. Through live video 
streaming, it helps to improve surveillance systems on the ongoing situation $[8,9]$.

In Bangladesh some of the virtual technologies were found to be used to confront COVID-19 pandemic. Among these technologies, telemedicine, video streaming, virtual conference, virtual court, virtual class room, online educating etc to maintain social and physical distancing so that the transmission of corona virus can be stopped across the country.

Telemedicine is one of the important VR technologies to explore awareness even in the remote corner of any country [10]. In Bangladesh this technology is found to be applied through varieties of government, non-government electronic media as well as social media to create awareness among the people about corona virus (COVID-19) transmission. In television and face book live program, the experts and experienced doctors and health workers were found to explain the severity of this rare disease. They also addressed the people how to follow the health rules to control its transmission. They also suggested testing them, in case of any symptom of COVID-19, and if the report is positive, they are asked to remain in quarantine, in case of severity, they are asked to be shifted to an isolation center.

Video Streaming is another virtual technology which is used in Bangladesh to tackle COVID-19 pandemic situation. In government, on government and social media, creating awareness among the people was found about corona virus (COVID-19) transmission through this VR technology. Some videos were produced by the government as well as some organizations like UNICEF on the basis of the activities that the people should do to avoid corona virus (COVID-19) transmission.

Except the, above, with the increasing of corona virus (COVID-19) transmission, most of the government and non-government activities of the country were found to be commenced with the virtual technologies. To avoid COVID-19 transmission, the judiciary department of Bangladesh decided to continue their activities through virtual court. At the same time, the Ministry of Education encouraged the educational institutions to continue their activities using virtual technology (VR). The Ministry of Health \& Family Planning, IEDCR, regularly addressing the press and the country men of the update of every 24 hours of new COVID19 positive cases and death tolls through video conference. Sheikh Hasina, the honorable Prime Minister of Bangladesh is closely observing the COVID-19 pandemic situation and advising the Ministry of Health, district commissioners as well as other responsible persons of the government to execute the initiatives taken by the government to stop corona virus (COVID-19) transmission in the country through video conference.

\section{Impact on Economy}

The wheel of economy of the country is turned to be almost stopped. The garments industries, mills, facto- ries, poultry and dairy farm, markets, shopping centers, etc are under lockdown due to maintain social distancing. Government has already declared stimulus package for the garments industries as well as for some other sectors so that the economy of the country may be reshaped in its own position [11]. Recently, the government has relaxed lockdown to some garments industries, markets and shopping centers and allowed them to run their business keeping social and physical distance along with maintaining all the rules of health and sanitation to stop COVID-19 transmission in the community [6]. But it is too difficult to monitor and control the people. So most of the mills, factories shop and markets are still remain closed. On the other hand, remittance is one of the greatest sources of economy of this country. As most of the workers have to return from abroad, this source of income has already reduced to a great extent. However, the government is trying to keep running the economy of the country. Bangladesh Army, RAB, and Police are continuously helping the marginal farmers by arranging social and physical distancing markets where they can sell and buy their products.

\section{An Overview of the Authors Regarding the Situation}

Corona Virus (COVID-19) pandemic is a global issue. Bangladesh is not out of it. Though it is a developing country, it left no stone unturned to control corona virus (COVID-19 transmission among the people across the country. But due to economic necessities or unwilling of the people to follow health rules, lockdown, physical and social distancing, the corona virus (COVID-19) transmission is increasing in an alarming scale in Bangladesh since 08 March, 2020 to till now. Hence this is right time for Bangladesh to think alternative initiatives to end this pandemic in Bangladesh otherwise it have to pay heavy death tolls.

\section{Limitations of the Study}

This was a short term secondary literature review but the situation is very critical in all aspects of human life. So, the study results might not be reflected fully in the original scenarios of the situation.

\section{Conclusion and Recommendations}

From this study, it is vivid that Corona Virus (COVID-19) transmission is increasing in an alarming rate in Bangladesh, retiring all the government and non-government responses. Hence the national task force needs to be more strict to stop community transmission of corona virus as well as a high-tech technology needs to be introduced to the physicians and health workers to take care of the COVID-19 patients in Bangladesh to end this pandemic.

\section{References}

1. (2020) Virtual press conference on COVID-19 (WHO).

2. (2020) National guidelines on clinical management of coro- 
navirus disease 2019 (Covid-19) (WHO) Disease control division, Directorate general of health services, Ministry of health \& family welfare, Government of the people's Republic of Bangladesh.

3. Chaolin Huang, Yeming Wang, Xingwang Li, Lili Ren, Jianping Zhao, et al. (2020) Clinical features of Patients infected with 2019 novel coronavirus in Wuhan, China, Lancet 395: 497-506.

4. Institute of epidemiology, diseases control and research (IEDCR), Bangladesh.

5. (2020) COVID 19 situation in Bangladesh.

6. (2020) Electronic, social and print media, Bangladesh.

7. (2020) COVID-19, situation report no. 10 (WHO), Bangladesh.
8. Singh RP, Javaid M, Kataria R, Tyagi M, Haleem A, et al. (2020) Significant applications of virtual reality for COVID-19 pandemic. Diabetes \& Metabolic Syndrome: Clinical Research \& Reviews 14: 661-664.

9. Singh RP, Javaid M, Haleem A, Suman R (2020) Internet of things (IoT) applications to fight against COVID-19 pandemic. Diabetes \& Metabolic Syndrome: Clinical Research \& Reviews 14: 521-524.

10. Vaishya R, Bahl S, Singh RP (2020) Letter to the editor in response to: Telemedicine for diabetes care in India during COVID19 pandemic and national lockdown period: Guidelines for physicians. Diabetes Metab Syndr 14: 687-688.

11. (2020) Online news conference by Sheikh Hasina, the Honorable Prime Minister of Bangladesh. 